\title{
The practice and promise of private land conservation
}

\author{
Michael Drescher ${ }^{1,2}$ and Jacob C. Brenner ${ }^{3}$
}

\begin{abstract}
In many countries around the globe, private freehold lands cover large areas. Conservation on these private lands, next to statutory protected areas, promises to play a critical role in efforts for reaching internationally agreed environmental protection targets. Lying at the heart of an emerging land system science, in which ecology, economics, geography, psychology, and other social sciences interact, private land conservation is reflecting the intertwined and multiscalar processes of our rapidly transforming world. Situated at this disciplinary meeting point, private land conservation invites a great breadth of approaches and cross-disciplinary work that offer deep insights into social and environmental change, often from surprising angles. Although many questions remain in private land conservation, we can now build on a large body of recent high-quality studies as we push this field forward in both research and practice. The Special Feature "Private Land Conservation - Landowner Motives, Policies, and Outcomes of Conservation Measures in Unprotected Landscapes" brings together contributions that explore the diversity of recent advances in private land conservation science. As an introduction to this Special Feature, first we are reviewing recent dynamics in important social-ecological drivers with bearing on private land conservation science. We go on to introduce the individual contributions to this Special Feature and then examine common themes as they are emerging from these papers, including the need for flexibility in conservation approaches, pursuit of community cobenefits of conservation, increasing consideration of environmental justice questions, and acknowledgment of the importance of social psychology in shaping private land conservation. We conclude with identification of knowledge gaps and recommendations for future research, as we advance from diagnostics to normative work in private land conservation science.
\end{abstract}

Key Words: conservation; environmental protection; land management; multidisciplinary; policy; practice; private landowner; socialecological

\section{INTRODUCTION}

Governments and conservation organizations worldwide have worked for many years toward the protection of biodiversity and other environmental values through the expansion of protected area networks (Butchart et al. 2010, Rands et al. 2010). Large gains have been made, yet the success remains limited. In part, this is because states have struggled to allocate land to statutory protected areas (PAs; Watson et al. 2014). Although some individual countries have met their commitments for PAs, many others have not (COPCBD 2016). And even once PAs are gazetted, they may not cover key centers of biological richness (Venter et al. 2018), fail to protect important species (Pimm et al. 2014), or produce trade-offs among their various purposes ( $\mathrm{Di}$ Moreno et al. 2015). If a global conservation strategy involved only public land and statutory PAs, we would be severely challenged to meet the 2020 targets established by the Convention on Biological Diversity (https://www.cbd.int/sp/targets/).

Fortunately, conservation also occurs on privately held lands in a multitude of ways, and this relatively sparsely documented phenomenon is the subject of this Special Feature. Private freehold lands cover large portions of many countries around the world (e.g., South Africa-73\%, USA-60\%, Namibia-44\%), and this pattern is even more pronounced in some subnational jurisdictions (e.g., Texas, USA-96\%, Scotland, UK- $88 \%$, Nova Scotia, Canada- $70 \%$, Victoria, Australia-62\%). Scientists, conservation practitioners, and landowners alike are increasingly appreciating that private land in the large, human-altered landscape matrix between statutory PAs plays a critical role in environmental protection (DeFries et al. 2007).

We do not dismiss the importance of statutory PAs, or suggest to focus exclusively on the private landscape matrix. Rather, in this
Special Feature we address the complexity of private land conservation (PLC) that should be part of a large-landscape conservation strategy (Trombulak and Baldwin 2010) involving private lands as well as state-managed PAs. In doing so, we focus on the various functions, motivations, barriers, and opportunities surrounding PLC, with a keen eye toward how these aspects manifest and interact within larger land systems (Kamal et al. 2015). The interplay of PLC and other conservation initiatives within larger social-ecological systems makes PLC a dynamic phenomenon that invites cross-disciplinary work in the form of conceptual synthesis, place-based case study, cross-regional comparison, and analysis of new issues through novel approaches and methods. We hope this Special Feature helps to guide researchers toward exciting new work while also inspiring more conservation action in this important, emerging field.

Over the last four decades, socio-political and environmental changes have transformed societies across the globe at an unprecedented rate (Steffen et al. 2015). Neoliberal globalization has been increasing worldwide interconnectivity, promoting international migration, and enabling natural resource capitalization and exploitation from afar (Eakin et al. 2014). Population growth in less industrialized countries and increasing rates of commodity consumption in more industrialized countries are linked to ever growing rates of resource extraction, land use intensity, and environmental impact (Schaffartzik et al. 2014). Amid these changes is downward pressure on government spending for environmental programs in most countries, which is straining public spending on statutory PAs, leading to downsizing, downgrading, or full degazettement (Mascia et al. 2014). At the confluence of all these dynamics is the way individuals, households, organizations, and societies use land

${ }^{1}$ School of Planning, University of Waterloo, Waterloo, Ontario, Canada, ${ }^{2}$ Vincent and Elinor Ostrom Workshop in Political Theory and Policy Analysis, Indiana University, Bloomington, Indiana, USA, ${ }^{3}$ Ithaca College, Ithaca, New York, USA 
(Foley et al. 2005). PLC lies at the heart of an emerging land system science, in which economics, ecology, geography, psychology, and other social sciences can be integrated to help us understand the complex ways in which PLC is changing along with intertwined and multiscalar processes of social and environmental change (Verburg et al. 2013).

Among the most pronounced changes in our world is our rapidly growing technical ability to collect, store, and process information, including remotely sensed information about changing land use and land cover (Rose et al. 2015, Turner et al. 2015). This information provides huge opportunities for evidencebased decisions to plan and manage land use, but it can raise concerns among private landowners about its use for planning and policy that affect their properties (Rao et al. 2006).

In private land management, a variety of factors are involved that change decision making from a purely rational economic choice to something much more complex (Lute et al. 2018). In conjunction with increasing availability of land use information and democratization of its access, we see an increasingly engaged and empowered population of private landowners less amicable to governmental or nongovernmental top-down control, dissatisfied with current land management governance, and wishing to be more directly involved in land use planning, certainly as it affects their own properties (Peterson and Liu 2008, Jacquet 2015). Consequently, there is a growing need for the conservation science community to recognize the implementation limitations of a purely science-driven conservation planning process (Reyers et al. 2010). Devolution of land use decision power to private landowners and comanagement of natural resources require even greater efforts by the conservation community to work openly with these landowners, to seriously consider their needs and perspectives, and to involve them as equal partners in the planning of land cover and land use change (Frost et al. 2006). Following this approach, a conservation planning process must address conservation goals on the same footing as economic and social goals of local populations (Halpern et al. 2013).

Although several decades ago research on PLC tended to focus on working lands and modifications to land use practices to make them more sustainable (Tikka and Kaupi 2003), today increasing attention is given to marginal, remote, or extreme lands, e.g., drylands. This shift in attention is caused by two main factors: (1) In an effort to increase agricultural efficiency, marginal lands are released from agricultural production. These lands are still in private ownership, but may provide new conservation opportunities in regions that are otherwise managed for their productive capacity (Queiroz et al. 2014). (2) Remote and extreme lands are increasingly attractive to the land development industry because of their often high amenity value, e.g, tranquility or viewshed, which in turn drives migration to these regions (Lekies et al. 2015). However, these regions frequently harbor unique environmental values and often are environmentally sensitive. Thus residential and infrastructure development in these areas, even at low density, create new conservation challenges (Taylor and Hurley 2016).

Though it increasingly seems that statutory PAs alone will fall short of commitments on conservation targets (COPCBD 2016), and the realization grows that PLC should play a role in reaching these targets (Kamal et al. 2015), much uncertainty remains about how to best achieve conservation goals through the involvement of private lands. Some of these uncertainties revolve around the financing of PLC schemes. To address these concerns, innovative financing mechanisms are being developed to fund conservation by private landowners (Lennox et al. 2017, Schuster et al. 2017). However, actual rollout and implementation of such schemes is still very unclear. The field of ecosystem service planning and management is seen by some as a promising solution to the question of PLC financing (Hein et al. 2013). However, paymentsfor-ecosystem-services (PES) regimes are no panacea. Many questions remain around how people's relationships with nature would change through this commodification of nature (Kosoy and Corbera 2010), how to ensure that costs and benefits from PES regimes are fair and equitable, and how the inevitable tradeoffs should be managed (Wegner 2016). In response to the strong emphasis on natural sciences and economics in the existing framework, scholars are currently reframing PES to be more inclusive to a variety of sciences and cultural perspectives (Díaz et al. 2018). At the same time, efforts of environmental organizations are intensifying to purchase private lands, purchase land use rights, or enter management agreements for conservation purposes (Parkhurst and Shogren 2003). These efforts also meet some challenges, ranging from questions about the appropriate legal tools for supporting large-scale land management regimes (Lausche et al. 2013) to the wisdom of committing to fixedboundary PAs while the environments they protect are altered by climate change and other larger scale forces (Armstrong et al. 2015).

\section{CONTRIBUTED PAPERS}

This Special Feature brings together 14 contributions covering a wide range of topics, approaches, and regions of the world. The diversity of these articles displays the variety of issues surrounding PLC. Landscapes range from remote and rural to built-up urban spaces, and they include forests, shrublands, and grasslands, as well as farms and neighborhoods. They also cover a range of scholarly perspectives, from ecological science, to ethnographic approaches, to policy and governance analysis. This variety speaks to the breadth, depth, and richness of PLC as a research field.

The 14 articles can be divided thematically into four groups: (1) social-psychological factors and linkages affecting environmental perception or behavior; (2) equity and justice in the distribution of benefits and burdens in PLC; (3) land cover and other environmental changes in association with PLC; and (4) socialecological integration and framing of PLC.

\section{Social-psychological links with environmental perceptions and behaviors}

The first article in this theme covers work by Niemiec et al. (2016) on the invasive exotic tree, albizia (Falcataria moluccana), in Hawaii, USA, focusing on the role of private landowners in landscape-scale management of biological invasions. The study employed a cross-sectional survey of 243 landowners to elucidate the influences of intrapersonal, interpersonal, and other contextual factors on actions taken to combat albizia invasions. The results suggest that social norms and a sense of reciprocity among landowners play important roles in motivating invasive species activism and management. This study sheds new light on 
the social dimensions of biological invasions, and it takes an important step toward a better understanding of the informal institutions governing invasive species management.

Ruseva et al. (2016) focused on examining norms and values, cooperation, and communication among land trust board members in the southern Appalachian region of the eastern USA. More often studied among individual landowners, these indicators of social capital provide insights into the conditions that enable or promote PLC among land conservation organizations. The results show that land trust success as perceived by board members depends on shared norms and values, organizational structure and networks, as well as volunteerism and financial support. This study provides a unique look behind the scenes of local nonprofit land conservation organizations, and its findings can help practitioners bridge gaps between their organizations and local landowners. It also provides valuable insights for land conservation practitioners seeking to better understand their own organizations.

Drescher et al. (2017) investigated several established socialpsychological determinants of proenvironmental behaviors and integrated them to develop a comprehensive model of landowner participation in a conservation tax incentive program in Ontario, Canada. Using responses to a survey of 800 program-eligible landowners, they contrasted program participants with nonparticipants. A novel aspect of their work is the investigation of the relative contributions of several social-psychological determinants of proenvironmental behavior in the same modeling framework. The study results reveal complex relationships among values, attitudes, and behaviors and emphasize the importance of education for conservation program participation. The results also point toward an association of political leaning with perceived personal obligation for conservation and suggest opportunities for PLC outside of government programs.

The fourth article in this theme, by Farmer et al. (2016), is focused on increasing understanding of the characteristics of landowners that are interested in protecting their land with conservation easements. Understanding these characteristics is useful for conservation organizations that are working to engage private owners in permanent land protection. Set in Indiana, USA, this study draws on the results of a survey of 500 landowner participants in a local conservation tax incentive program. The study results suggest a set of three predictors of interest in conservation easements: perception of local landscape change, outdoor recreation activity, and membership in an environmental organization. The authors introduce the term "functional leisure" to represent land stewardship activities that landowners enjoy.

The fifth and final article in this theme addresses the relative importance of financial and nonfinancial factors in initiating and maintaining voluntary PLC. Selinske et al. (2016) present three case studies, two in Australia and one in South Africa, including in-depth insights from the close examination of various types of conservation programs. The authors found that financial promotion might incentivize initial participation, but sustained engagement depends on a diverse and flexible set of nonfinancial policy instruments. They raise key considerations for governments and nonprofit land conservation organizations aiming to promote long-term stewardship among private landowners.

\section{Equity and justice}

The first article in this theme is contributed by Olive (2016). Set in Indiana, Ohio, and Utah, USA, as well as Ontario, Canada, this study uses "fairness" as a lens to investigate landowner perceptions of the distribution of burdens in the application of species-at-risk legislation. Drawing on 141 interviews, this study inquired which forms of environmental justice were most pertinent to landowners and whether this coincided with environmental justice as approached by species-at-risk legislation. The results indicate that private landowners find it very important to be involved in planning and implementation of species conservation activities, as well as being recognized for their efforts. These key interests are quite different from the legislative emphasis on landowner compensation and should be addressed in future policy amendments.

Villamagna et al. (2017) take a quantitative and spatially explicit approach to the distribution of environmental benefits from public-private conservation networks. With datasets of federal, state, and local private easement lands in North Carolina and Virginia, USA, they used a geographic information system to model ecosystem service flows from protected natural areas to nearby residents. Focusing on variability in distribution by race, they found that hydrological benefit zones of federal PAs underrepresented minority beneficiaries, while state and private PAs included up to $25 \%$ more minority beneficiaries. Regarding socioeconomic class, benefit zones around private PAs included residents of considerably higher household income. The finding that benefits of PLC can be unequally distributed among groups of differing race and socioeconomic class deserves serious consideration. Addressing these equity issues could be important for building widespread support for large-scale conservation initiatives.

The third contribution in this theme is an article by Rissman et al. (2017), which addresses opportunities and barriers to the use of geospatial data in the planning and management of conservation on private land. The authors present insights about data access and availability from four case studies of institutional conservation databases in the USA. Although the exact reasons for lack of data access or availability differ from case to case, issues of institutional capacity and privacy concerns are recurring themes. Recommendations for policy changes include tailoring data access privileges according to data uses and privacy concerns, and enabling legal mechanisms that facilitate data access.

\section{Land-cover and other environmental changes}

The first article in this theme is contributed by Syphard et al. (2016). Applying a modeling approach to regions with rapid residential development in San Diego County, California, USA, the authors investigated whether private land acquisitions could satisfy both biodiversity and wildfire management objectives, or whether these objectives are mutually exclusive. The results suggest differences in outcomes among various land acquisition strategies. Focusing land acquisition either on lands with high biodiversity values or on lands prone to wildfire, both resulted in higher biodiversity conservation and fire risk reduction, compared to land acquisition focused on cost minimization. The results suggest that it is possible to simultaneously pursue environmental and human values and may be applicable to other regions where biodiversity richness and high fire risk overlap. 
The second article in this theme by Farley et al. (2017) is also located in San Diego County, California, USA, and focuses on rangelands. Based on geographic information system analyses of land use changes and 13 in-depth interviews with ranchers, the authors investigated the rate of rangeland conversion and participation in rangeland conservation programs. The results indicate a rangeland loss of $3.1 \%$ over the 19 -year study period and an intricate mix of variables shaping ranchers' attitudes toward participation in conservation programs. Although most rangeland was lost to urbanization, ranchers viewed rangeland conversion to public parkland as another threat. Acknowledging and effectively addressing ranchers' social values, land use ethics, and conservation-beneficial land use practices may often be critical to ranchers' engagement in conservation programs.

\section{Social-ecological systems: framing and integration}

The first contribution to this theme is an article based on a case study by Duff et al. (2017) of an eco-labeling and farm stewardship initiative with a $20+$ year history in Wisconsin, USA. The authors examined this case within a social-ecological systems framework and developed a generalized "Capacity-Building Stewardship Model" that points toward mechanisms for building commitment to conservation among agricultural producers. The model identifies some of the challenges faced in scaling up farmlevel stewardship to the regional level, suggests practical support mechanisms for addressing these challenges, and highlights the important role of agricultural networks in nurturing the development of agricultural producers as land stewards. The authors close by pointing out some limitations-in the eco-labeling, farm stewardship initiative, and the model itself.

The next article by Salliou and Barnaud (2017) also addresses stewardship on agricultural lands, in this case in southwestern France. In-depth interviews were carried out with 30 local stakeholders, including fruit growers, livestock breeders, crop advisers, and retired farm owners. The interviews elicited attitudes about land management vis-à-vis biological pest control and used these attitudes to construct stakeholders' mental models. Researchers had demonstrated the value of natural areas as habitats for natural enemies of pests, and policy makers had committed to this notion through land use policies. Agricultural producers, however, widely viewed natural areas as havens for pests, not as habitats for biological pest-control agents. The results suggest a need for research to better understand, communicate across, and close the gap that exists between scientists, policy makers, and farmers with regard to the ecology of complex working landscapes.

The third article in this theme by Quinn and Wood (2017) draws on two case studies situated in Nebraska as well as North and South Carolina, USA. It argues that private land conservation can be planned and implemented more effectively when viewed through the lens of coupled human-and-natural systems (CHANS). The authors use the two case studies to illustrate the connections between human and natural subsystems at various scales and explain how private land conservation can express CHANS characteristics such as scale issues, feedbacks, time lags, and thresholds. They recommend the CHANS framework as a tool facilitating research design, interpretation, and dialogue.

The final article in this theme contributed by Clements et al. (2016) is set in the Western and Eastern Cape Provinces of South Africa and focuses on socioeconomic drivers of predator species composition (lion, Panthera leo, and cheetah, Acinonyx jubatus) and abundance in private land conservation areas. The results indicate that the presence and amount of large predator species is associated with the use of private conservation areas for income generation from wildlife tourism, and the rate of income that is generated. The results also suggest that maintained lion densities mostly were within sustainable levels given observed prey densities, while this was not the case for cheetah. The authors conclude that current wild life management policies are not always effective at controlling potentially negative ecological consequences stemming from the pursuit of international tourism revenues.

\section{CONCLUSIONS AND RECOMMENDATIONS: ADVANCING THE SCIENCE OF PRIVATE LAND CONSERVATION}

The contributions in this Special Feature lead to several conclusions relevant to future work in PLC research, policy, and practice. Several of the studies suggest a need for PLC programs to remain, or become more flexible. Flexibility in scope and parameters enables PLC initiatives to reach and resonate with a diverse population of private landowners, each of whom may have their specific perspectives and requirements. The richer the literature on landowner values and motivations gets, the clearer it becomes that no "one-size-fits-all" policy could include the multitude of people that might have an interest in proenvironmental land management activities (Moon et al. 2012). Flexibility is also needed in the face of changing biophysical, social, and political circumstances (Peterson et al. 2003). For example, the long-term resilience of land conservation approaches such as conservation easements might be enhanced, if mechanisms would be employed that provided for land use flexibility as landownership and environmental conditions are changing (Rissman 2011). This flexibility must be balanced, however, with approaches that allow for continuity in conservation management over the long term and larger scales (Margules and Pressey 2000). Costs and benefits (including uncertainty thereof) must be communicated as clearly as possible by scientists and land conservation organizations so that fears of undue burdens on private landowners can be assuaged. At the same time, land conservation organizations and scientists (as technical and general experts) must listen to and seriously consider the insights and concerns of private landowners and other local stakeholders. This multilateral communication should not be limited to expertise and insights per se, but should also include value systems and cultural structures underlying both the status quo and proposed conservation initiatives (Díaz et al. 2018). For example, a productive discussion of the opportunity costs of conservation versus development should include not only perspectives of technical experts but also those of landowning laypeople. Flexibility in both the PLC programs themselves and the processes by which they are implemented may alleviate landowners' fears of carrying the burden of conservation without reaping the benefits (Rissman 2011).

Closely related to concerns about flexibility in PLC mechanisms and procedures are issues of equity across pre-existing social groups. Costs and benefits may be impossible to realize in equal measure among all groups at all times. The spatially uneven distribution of arable land, ecosystems, valued biota, political 
jurisdictions, and land tenure will inevitably produce unevenness (Forman 1995) in land conservation. However, social inequities should be laid bare and acknowledged to the best of our research capabilities, and addressed to the best of our policy making capabilities. Today we know too much about PLC to let these equity issues remain hidden. Some of the empirical insights provided by authors featured here call for continued theoretical research into PLC equity issues, and more policy attention to them as well. The critical "parks and people" literature has done much for the social studies of statutory PAs (Brockington et al. 2008). It seems time for more critical social science on PLC equity as well.

Several of the articles here suggest that conservation measures and programs may be most impactful if they simultaneously pursue several goals. Similarly, private landowners will be more receptive to conservation measures and programs if their application allows them to pursue a range of goals, not just conservation per se. Of course, some conservation measures employ this approach already, such as conservation easements that allow private landowners to conserve land while obtaining income and property tax benefits (Gustanski and Squires 2000). However, these approaches can be expanded by addressing a more diverse range of cobenefits, and clarifying them to landowners. All too often private landowners feel that they are caught between forces that put financial and other pressures on them, and in these situations conservation acts as a threat (McCarthy 2002). Implementing such approaches may require reconciling interests at differing scales, because private individuals are more likely to make short-term cost-benefit judgments, while conservation efforts mostly require long-term and large-scale perspectives. Barriers to overcome include conservation efficiency issues such nonadditionality and perverse incentives, especially if conservation cobenefits are financial as in the case of paymentsfor-ecosystem services (Lundgren et al. 2018).

Finally, several of the articles in this Special Feature highlight the importance of an informal milieu of social norms, networks, and institutions in shaping PLC planning, implementation, and outcomes. Intangible aspects such as trust, reciprocity, or solidarity among stakeholders appear to matter more, and in different ways, than most researchers understood several years ago. These factors have not been well represented by the prevailing emphasis on ecological-scientific and economic approaches (Pretty and Smith 2004). The lessons from these discoveries are numerous and profound, and they potentially affect not only landowners, but also agents of land conservation organizations, government officials, and even conservation scientists. More research is needed to better understand not just what goes on in landowners' own minds, but also how those values and motivations are shaped by the interactions individual landowners have with their social networks and other stakeholders (Fisher and Ruseva 2010).

In spite of the proliferation of high-quality literature on PLC in recent years, additional questions remain. They focus on how PLC can address emerging and growing issues such as the following: (1) corporate "land-grabbing," its associated land-tenure shakeups, and the changes it imposes on rural communities and their relationships with rural environments (Hall et al. 2015), (2) conservation in rapidly growing peri-urban areas where, under weaker land use controls (Nilon et al. 2017), the economic interests and political influence of developers and other elites collide with public interests in conservation and ecosystem service protection (Bekessy et al. 2012), (3) complex and dynamic interactions between factors such as climate change and invasive species (Mainka and Howard 2010), and (4) emergent opportunities for conservation, such as (a) the release of marginal lands from agricultural production and their concomitant reconversion to more natural conditions, and (b) degrowth or decay in urban regions that can be reoccupied by natural systems to achieve conservation goals and provide ecosystem services close to the largest concentrations of human populations (Hunter 2014).

The field of private land conservation lies at the confluence of a great many disciplines. Ecology and economics have long been recognized as contributing to our understanding of private land management. However, increasingly the contributions of other disciplines from among the social sciences are recognized as vital to PLC and its role in broader conservation initiatives (Moon et al. 2014). Given our increasing technological sophistication in managing large amounts of data and monitoring land dynamics, we are in a position of great and growing opportunity to make forward-looking and evidenced-based decisions about PLC across multiple scales, from individual parcels to larger regions. Moreover, given our increasing multidisciplinary sophistication in understanding the underlying social dimensions of land use and management, we are in a better position than ever to acknowledge social complexity, equity, and context when making PLC decisions. The next step in private land conservation science may be to move from diagnostics to normative work, to move from understanding to planning, in this complex and multifaceted field that has so many important implications for general conservation science and beyond. Although many questions remain in PLC, we can nevertheless build on a firm and broadening understanding as we advance this field in both research and practice.

Responses to this article can be read online at: http://www.ecologyandsociety.org/issues/responses. php/10020

\section{Acknowledgments:}

The guest editors are grateful to all authors and reviewers for their contributions to this Special Feature.

\section{LITERATURE CITED}

Armstrong, P. R., E. R. Larson, S. T. Jackson, D. F. Sax, P. Simonin, B. Blossey, N. Green, M. L. Klein, L. Lester, T. H. Ricketts, M. C. Runge, and M. R. Shaw. 2015. Are conservation organizations configured for effective adaptation to global change? Frontiers in Ecology and the Environment 13(3):163-169. http://dx.doi.org/10.1890/130352

Bekessy, S. A., M. White, A. Gordon, A. Moilanen, M. A. Mccarthy, and B. A. Wintle. 2012. Transparent planning for biodiversity and development in the urban fringe. Landscape and 
Urban Planning 108(2-4):140-149. http://dx.doi.org/10.1016/j. landurbplan.2012.09.001

Brockington, D., R. Duffy, and J. Igoe. 2008. Nature unbound: conservation, capitalism, and the future of protected areas. Earthscan, London, UK.

Butchart, S. H., M. Walpole, B. Collen, A. van Strien, J. P. Scharlemann, R. E. Almond, J. E. Baillie, B. Bomhard, C. Brown, J. Bruno, K. E. Carpenter, G. M. Carr, J. Chanson, A. M. Chenery, J. Csirke, N. C. Davidson, F. Dentener, M. Foster, A. Galli, J. N. Galloway, P. Genovesi, R. D. Gregory, M. Hockings, V. Kapos, J. F. Lamarque, F. Leverington, J. Loh, M. A. McGeoch, L. McRae, A. Minasyan, M. Hernández Morcillo, T. E. Oldfield, D. Pauly, S. Quader, C. Revenga, J. R. Sauer, B. Skolnik, D. Spear, D. Stanwell-Smith, S. N. Stuart, A. Symes, M. Tierney, T. D. Tyrrell, J. C. Vié, and R. Watson. 2010. Global biodiversity: indicators of recent declines. Science 328(5982):1164-1168. http:// dx.doi.org/10.1126/science.1187512

Clements, H. S., G. S. Cumming, and G. I. H. Kerley. 2016. Predators on private land: broad-scale socioeconomic interactions influence large predator management. Ecology and Society 21(2):45. http://dx.doi.org/10.5751/ES-08607-210245

Conference of the Parties to the Convention on Biological Diversity (COPCBD). 2016. Updated analysis of the contribution of targets established by parties and progress towards the Aichi Biodiversity Targets. UNEP/CBD/COP/13/8/Add.2/Rev.1. Conference of the Parties to the Convention on Biological Diversity, Cancun, Mexico.

DeFries, R., A. Hansen, B. L. Turner, R. Reid and J. Liu 2007. Land use change around protected areas: management to balance human needs and ecological function. Ecological Applications 17 (4):1031-1038. http://dx.doi.org/10.1890/05-1111

Di Moreno, M., H. M. Stuart, S. H. Butchart, P. Visconti, G. M. Buchanan, G. F. Ficetola, and C. Rondinini. 2015. Synergies and trade-offs in achieving global biodiversity targets. Conservation Biology 30(1):189-195. http://dx.doi.org/10.1111/cobi.12559

Díaz, S., U. Pascual, M. Stenseke, B. Martín-López, R. T. Watson, Z. Molnár, R. Hill, K. M. A. Chan, I. A. Baste, K. A. Brauman, S. Polasky, A. Church, M. Lonsdale, A. Larigauderie, P. W. Leadley, A. P. E. van Oudenhoven, F. van der Plaat, M. Schröter, S. Lavorel, Y. Aumeeruddy-Thomas, E. Bukvareva, K. Davies, S. Demissew, G. Erpul, P. Failler, C. A. Guerra, C. L. Hewitt, H. Keune, S. Lindley, and Y. Shirayama. 2018. Assessing nature's contributions to people. Science 359(6373):270-272. http://dx.doi. org/10.1126/science.aap8826

Drescher, M., G. K. Warriner, J. R. Farmer, and B. M. H. Larson. 2017. Private landowners and environmental conservation: a case study of social-psychological determinants of conservation program participation in Ontario. Ecology and Society 22(1):44. http://dx.doi.org/10.5751/ES-09118-220144

Duff, A. J., P. H. Zedler, J. A. Barzen, and D. L. Knuteson. 2017. The capacity-building stewardship model: assessment of an agricultural network as a mechanism for improving regional agroecosystem sustainability. Ecology and Society $22(1): 45$. http:// dx.doi.org/10.5751/ES-09146-220145
Eakin, H., R. DeFries, S. Kerr, E. F. Lambin, J. Liu, P. J. Marcotullio, P. Messerli, A. Reenberg, X. Rueda, S. R. Swaffield, B. Wicke, and K. Zimmerer. 2014. Significance of telecoupling for exploration of land-use change. Pages 141-161 in K. C. Seto and A. Reenberg, editors. Rethinking global land use in an urban era. Strüngmann Forum Reports 14. MIT Press, Cambridge, Massachusetts, USA. http://dx.doi.org/10.7551/mitpress/97802$\underline{62026901.003 .0008}$

Farley, K. A., K. Walsh, and A. S. Levine. 2017. Opportunities and obstacles for rangeland conservation in San Diego County, California, USA. Ecology and Society 22(1):38. http://dx.doi. org/10.5751/ES-09077-220138

Farmer, J. R., J. C. Brenner, M. Drescher, S. Dickinson, and E. G. Knackmuhs. 2016. Perpetual private land conservation: the case for outdoor recreation and functional leisure. Ecology and Society 21(2):46. http://dx.doi.org/10.5751/ES-08515-210246

Fisher, B. C., and T. B. Ruseva. 2010. What is happening in and outside America's private woodlands? Journal of Forestry 108 (6):304-306.

Foley, J. A., R. DeFries, G. P. Asner, C. Barford, G. Bonan, S. R. Carpenter, F. S. Chapin, M. T. Coe, G. C. Daily, H. K. Gibbs, J. H. Helkowski, T. Holloway, E. A. Howard, C. J. Kucharik, C. Monfreda, J. A. Patz, I. C. Prentice, N. Ramankutty, and P. K. Snyde. 2005. Global consequences of land use. Science 309:570-574. http://dx.doi.org/10.1126/science.1111772

Forman, R. T. T. 1995. Land mosaics: the ecology of landscapes and regions. Cambridge University Press, Cambridge, UK.

Frost, P., B. Campbell, G. Medina, and L. Usongo. 2006. Landscape-scale approaches for integrated natural resource management in tropical forest landscapes. Ecology and Society 11 (2):30. http://dx.doi.org/10.5751/ES-01932-110230

Gustanski, J. A., and R. H. Squires. 2000. Protecting the land: conservation easements past, present, and future. Island, Washington, D.C., USA.

Hall, R., M. Edelman, S. M. Borras Jr, I. Scoones, B. White, and W. Wolford. 2015. Resistance, acquiescence or incorporation? An introduction to land grabbing and political reactions 'from below. ' Journal of Peasant Studies 42(3-4):467-488. http://dx.doi. org/10.1080/03066150.2015.1036746

Halpern, B. S., C. J. Klein, C. J. Brown, M. Beger, H. S. Grantham, S. Mangubhai, M. Ruckelshaus, V. J. Tulloch, M. Watts, C. White, and H. P. Possingham. 2013. Achieving the triple bottom line in the face of inherent trade-offs among social equity, economic return, and conservation. Proceedings of the National Academy of Sciences of the United States of America 110(15):6229-6234. http://dx.doi.org/10.1073/pnas.1217689110

Hein, L., D. C. Miller, R. de Groot. 2013. Payments for ecosystem services and the financing of global biodiversity conservation. Current Opinion in Environmental Sustainability 5(1):87-93. http:// dx.doi.org/10.1016/j.cosust.2012.12.004

Hunter, P. 2014. Brown is the new green: Brownfield sites often harbour a surprisingly large amount of biodiversity. $E M B O$ Reports 15:1223-1330. http://dx.doi.org/10.15252/embr.201439736 
Jacquet, J. B. 2015. The rise of "private participation" in the planning of energy projects in the rural United States. Society \& Natural Resources 28(3):231-245. http://dx.doi.org/10.1080/08941920.2014 .945056

Kamal, S., M. Grodzińska-Jurczak, and G. Brown. 2015. Conservation on private land: a review of global strategies with a proposed classification system. Journal of Environmental Planning and Management 58(4):576-597. http://dx.doi. org/10.1080/09640568.2013.875463

Kosoy, N., and E. Corbera. 2010. Payments for ecosystem services as commodity fetishism. Ecological Economics 69:1228-1236. http://dx.doi.org/10.1016/j.ecolecon.2009.11.002

Lausche, B., D. Farrier, J. Verschuuren, A. G. M. La Viña, A. Trouwborst, C.-H. Born, and L. Aug. 2013. The legal aspects of connectivity conservation - a concept paper. IUCN, Gland, Switzerland.

Lekies, K. S., D. Matarrita-Cascante, R. Schewe, and R. Winkler. 2015. Amenity migration in the new global economy: current issues and research priorities. Society \& Natural Resources 28 (10):1144-1151. http://dx.doi.org/10.1080/08941920.2015.1054571

Lennox, G. D., J. Fargione, S. Spector, G. Williams, and P. R. Armsworth. 2017. The value of flexibility in conservation financing. Conservation Biology 31(3):666-674. http://dx.doi. org/10.1111/cobi.12771

Lundgren, L., U. Martin Persson, F. Alpizar, and K. Lindgren. 2018. Context matters: exploring the cost-effectiveness of fixed payments and procurement auctions for PES. Ecological Economics 146:347-358. http://dx.doi.org/10.1016/j.ecolecon.2017.11.021

Lute, M. L., C. R. Gillespie, D. R. Martin, and J. J. Fontaine. 2018. Landowner and practitioner perspectives on private land conservation programs. Society \& Natural Resources 31 (2):218-231. http://dx.doi.org/10.1080/08941920.2017.1376139

Mainka, S. A., and G. W. Howard. 2010. Climate change and invasive species: double jeopardy. Integrative Zoology 5:102-111. http://dx.doi.org/10.1111/j.1749-4877.2010.00193.x

Margules, C. R., and R. L. Pressey. 2000. Systematic conservation planning. Nature 405:243-253. http://dx.doi.org/10.1038/35012251

Mascia, M. B., S. Pailler, R. Krithivasan, V. Roshchanka, D. Burns, M. J. Mlotha, D. R. Murray, and N. Peng. 2014. Protected area downgrading, downsizing, and degazettement (PADDD) in Africa, Asia, and Latin America and the Caribbean, 1900-2010. Biological Conservation 169:355-361. http://dx.doi.org/10.1016/j. biocon.2013.11.021

McCarthy, J. 2002. First world political ecology: lessons from the wise use movement. Environment and Planning A: Economy and Space 34(7):1281-1302. http://dx.doi.org/10.1068/a3526

Moon, K., V. M. Adams, S. R. Januchowski-Hartley, M. Polyakov, M. Mills, D. Biggs, A. T. Knight, E. T. Game, and C. M. Raymond. 2014. A multidisciplinary conceptualization of conservation opportunity. Conservation Biology 28(6):1484-1496. http://dx.doi.org/10.1111/cobi.12408

Moon, K., N. Marshall, and C. Cocklin. 2012. Personal circumstances and social characteristics as determinants of landholder participation in biodiversity conservation programs. Journal of Environmental Management 113:292-300. http://dx. doi.org/10.1016/j.jenvman.2012.09.003

Niemiec, R. M., N. M. Ardoin, C. B. Wharton, and G. P. Asner. 2016. Motivating residents to combat invasive species on private lands: social norms and community reciprocity. Ecology and Society 21(2):30. http://dx.doi.org/10.5751/ES-08362-210230

Nilon, C. H., M. F. J. Aronson, S. S. Cilliers, C. Dobbs, L. J. Frazee, M. A. Goddard, K. M. O'Neill, D. Roberts, E. K. Stander, P. W. M. Winter, and K. P. Yocom. 2017. Planning for the future of urban biodiversity: a global review of city-scale initiatives. BioScience 67(4):332-342. http://dx.doi.org/10.1093/biosci/bix012

Olive, A. 2016. It is just not fair: the Endangered Species Act in the United States and Ontario. Ecology and Society 21(3):13. http://dx.doi.org/10.5751/ES-08627-210313

Parkhurst, G. M. and J. F. Shogren. 2003. Evaluating incentive mechanisms for conserving habitat. Natural Resources Journal 43 (4):1093-1150.

Peterson, G. D., G. S. Cumming, and S. R. Carpenter. 2003. Scenario planning: a tool for conservation in an uncertain world. Conservation Biology 17(2):358-366. http://dx.doi.org/10.1046/ j.1523-1739.2003.01491.x

Peterson, M. N., and J. Liu. 2008. Property rights and landscape planning in the intermountain west: The Teton Valley case. Landscape and Urban Planning 86(2):126-133. http://dx.doi. org/10.1016/j.landurbplan.2008.01.003

Pimm, S. L., C. N. Jenkins, R. Abell, T. M. Brooks, J. L. Gittleman, L. N. Joppa, P. H. Raven, C. M. Roberts, and J. O. Sexton. 2014. The biodiversity of species and their rates of extinction, distribution, and protection. Science 344(6187):1246752. http:// dx.doi.org/10.1126/science. 1246752

Pretty, J., and D. Smith. 2004. Social capital in biodiversity conservation and management. Conservation Biology 18 (3):631-638. http://dx.doi.org/10.1111/j.1523-1739.2004.00126.x

Queiroz, C., R. Beilin, C. Folke, and R. Lindborg. 2014. Farmland abandonment: threat or opportunity for biodiversity conservation? A global review. Frontiers in Ecology and the Environment 12(5):288-296. http://dx.doi.org/10.1890/120348

Quinn, J. E., and J. M. Wood. 2017. Application of a coupled human natural system framework to organize and frame challenges and opportunities for biodiversity conservation on private lands. Ecology and Society 22(1):39. http://dx.doi. org/10.5751/ES-09132-220139

Rands, M. R., W. M. Adams, L. Bennun, S. H. Butchart, A. Clements, D. Coomes, A. Entwistle, I. Hodge, V. Kapos, J. P. Scharlemann, W. J. Sutherland, and B. Vira. 2010. Biodiversity conservation: challenges beyond 2010. Science 329(5997):1298-1303. http://dx.doi.org/10.1126/science.1189138

Rao, M., and K. R. Sridhara Murthi. 2006. Keeping up with remote sensing and GI advances-policy and legal perspectives. Space Policy 22(4):262-273. http://dx.doi.org/10.1016/j. spacepol.2006.09.001 
Reyers, B., D. J. Roux, R. M. Cowling, A. E. Ginsburg, J. L. Nel, and P. O. Farrell. 2010. Conservation planning as a transdisciplinary process. Conservation Biology 24(4):957-965. http://dx.doi.org/10.1111/j.1523-1739.2010.01497.x

Rissman, A. R. 2011. Evaluating conservation effectiveness and adaptation in dynamic landscapes. Law and Contemporary Problems 74(4):145-173.

Rissman, A. R., J. Owley, A. W. L'Roe, A. Wilson Morris, and C. B. Wardropper. 2017. Public access to spatial data on private-land conservation. Ecology and Society 22(2):24. http://dx.doi. org/10.5751/ES-09330-220224

Rose, R. A., D. Byler, J. R. Eastman, E. Fleishman, G. Geller, S. Goetz, L. Guild, H. Hamilton, M. Hansen, R. Headley, J. Hewson, N. Horning, B. A. Kaplin, N. Laporte, A. Leidner, P. Leimgruber, J. Morisette, J. Musinsky, L. Pintea, A. Prados, V. C. Radeloff, M. Rowen, S. Saatchi, S. Schill, K. Tabor, W. Turner, A. Vodacek, J. Vogelmann, M. Wegmann, D. Wilkie, and C. Wilson. 2015. Ten ways remote sensing can contribute to conservation. Conservation Biology 29(2):350-359. http://dx.doi. org/10.1111/cobi.12397

Ruseva, T. B., J. R. Farmer, and C. Chancellor. 2016. Networking for conservation: social capital and perceptions of organizational success among land trust boards. Ecology and Society 21(2):50. http://dx.doi.org/10.5751/ES-08618-210250

Salliou, N., and C. Barnaud. 2017. Landscape and biodiversity as new resources for agro-ecology? Insights from farmers' perspectives. Ecology and Society 22(2):16. http://dx.doi. org/10.5751/ES-09249-220216

Schaffartzik, A., A. Mayer, S. Gingrich, N. Eisenmenger, C. Loy, and F. Krausmann. 2014. The global metabolic transition: regional patterns and trends of global material flows, 1950-2010. Global Environmental Change 26(1):87-97. http://dx.doi. org/10.1016/j.gloenvcha.2014.03.013

Schuster, R., E. A. Law, A. D. Rodewald, T. G. Martin, K. A. Wilson, M. Watts, H. P. Possingham, and P. Arcese. 2017. Tax shifting and incentives for biodiversity conservation on private lands. Conservation Letters. http://dx.doi.org/10.1111/conl.12377

Selinske, M. J., B. Cooke, N. Torabi, M. J. Hardy, A. T. Knight, and S. A. Bekessy. 2016. Locating financial incentives among diverse motivations for long-term private land conservation. Ecology and Society 22(2):7. http://dx.doi.org/10.5751/ES-09148-220207

Steffen, W., W. Broadgate, L. Deutsch, O. Gaffney, and C. Ludwig. 2015. The trajectory of the Anthropocene: the great acceleration. Anthropocene Review 2(1):81-98. http://dx.doi.org/10.1177/2053$\underline{019614564785}$

Syphard, A. D., V. Butsic, A. Bar-Massada, J. E. Keeley, J. A. Tracey, and R. N. Fisher. 2016. Setting priorities for private land conservation in fire-prone landscapes: are fire risk reduction and biodiversity conservation competing or compatible objectives? Ecology and Society 21(3):2. http://dx.doi.org/10.5751/ES-08410-210302

Taylor, L. E., and P. T. Hurley. 2016. Introduction: the broad contours of exurban landscape change. Pages 1-29 in L. E. Taylor and P. T. Hurley, editors. A comparative political ecology of Exurbia. Springer, Cham, Switzerland. http://dx.doi. org/10.1007/978-3-319-29462-9 1
Tikka, P. M., and P. Kauppi. 2003. Introduction to special issue: protecting nature on private land - from conflicts to agreements. Environmental Science \& Policy 6:193-194. http://dx.doi. org/10.1016/S1462-9011(03)00047-9

Trombulak, S. C., and R. F. Baldwin, editors. 2010. Landscapescale conservation planning. Springer, Dordrecht, The Netherlands. $\underline{\text { http://dx.doi.org/10.1007/978-90-481-9575-6 }}$

Turner, W., C. Rondinini, N. Pettorelli, B. Mora, A. K. Leidner, Z. Szantoi, G. Buchanan, S. Dech, J. Dwyer, M. Herold, L. P. Koh, P. Leimgruber, H. Taubenboeck, M. Wegmann, M. Wikelski, and C. Woodcock. 2015. Free and open-access satellite data are key to biodiversity conservation. Biological Conservation 182:173-176. http://dx.doi.org/10.1016/j.biocon.2014.11.048

Venter, O., A. Magrach, N. Outram, C. J. Klein, H. P. Possingham, M. Di Marco, and J. E. M. Watson. 2018. Bias in protected-area location and its effects on long-term aspirations of biodiversity conventions. Conservation Biology 32(1):127-134. http://dx.doi. org/10.1111/cobi.12970

Verburg, P. H, K.-H. Erb, O. Mertz, and G. Espindola. 2013. Land system science: between global challenges and local realities. Current Opinion in Environmental Sustainability 5(5):433-437. http://dx.doi.org/10.1016/j.cosust.2013.08.001

Villamagna, A. M., B. Mogolloón, and P. L. Angermeier 2017. Inequity in ecosystem service delivery: socioeconomic gaps in the public-private conservation network. Ecology and Society 22 (1):36. http://dx.doi.org/10.5751/ES-09021-220136

Watson, J. E. M., N. Dudley, D. B. Segan, and M. Hockings. 2014. The performance and potential of protected areas. Nature 515 (7525):67-73. http://dx.doi.org/10.1038/nature13947

Wegner, G. I. 2016. Payments for ecosystem services (PES): a flexible, participatory, and integrated approach for improved conservation and equity outcomes. Environment, Development and Sustainability 18(3):617-644. http://dx.doi.org/10.1007/ s10668-015-9673-7 